Матија Нешовић

Универзитет у Београду

Филолошки факултет

Катедра за славистику

nesovic1998@gmail.com
УДК 81'23:811.163.41'373.235

https://doi.org/10.18485/slavistika.2019.23.2.6

Оригинални научни рад примљено 04.03.2019.

прихваћено за штампу 10.10.2019.

\title{
НАЗИВИ СРПСКИХ СЕЛА И ДЕЛОВА ГРАДОВА У ВЕРБАЛНИМ АСОЦИЈАЦИЈАМА ГОВОРНИКАิ СРПСКОГ ЈЕЗИКА*
}

У раду се помоћу резултата̂ асоцијативног експеримента анализира корпус од укупно сто топонима, и то назива села и делова градова у Србији. Главни циљ рада јесте да се на материјалу српског језика укаже на све језичке и ванјезичке факторе који могу утицати на концептуализацију географских објеката. Издвајањем и типологизацијом таквих фактора стиче се јаснија представа о природи концептуализације географских објеката. Истраживање је показало да реакције могу бити емпиријски мотивисане, али и засноване искључиво на интегралним језичким особинама стимулуса̂. Премда је наше истраживање првенствено когнитивистички усмерено, кроз поједине реакције испитаника̂ могу се очитати и одређени лингвокултуролошки подаци. У раду се, такође, проблематизује питање топонимске семантике, те се разматра однос појединих типова реакција према лексичком значењу топонима̂.

Кључне речи: топоними, концептуализација, асоцијативни експеримент, топонимска семантика, српски језик.

Using the results of an associative experiment, a corpus of one hundred Serbian place names, both in urban and rural areas, will be analyzed in this paper. The main objective of the paper, based on linguistic data in the Serbian language, is to draw attention to all linguistic and extra-linguistic factors that could affect the conceptualization of geographic objects. By isolating such factors and performing a typological analysis, a clearer picture of how geographic objects are conceptualized is formed. The research has shown that reactions may be empirically motivated, but also based on the integral linguistic properties of stimuli alone. Although this research was primarily cognitively oriented, certain linguocultural data could be obtained from the reactions of respondents. The paper further delves into the issue of toponym semantics, and the correlation between specific types of reactions and the lexical meaning of toponyms is taken into consideration.

Keywords: toponyms, conceptualization, associative experiment, toponym semantics, Serbian language.

\section{1. Уводна разматрања, предмет и циљеви рада}

Темељном интердисциплинарном анализом топонимске структуре откривају се богати наноси минулих времена, етничких, културних и језичких превирања (исп. Драгићевић 2007: 23). Због тога су топоними нарочито захвални за дијахронијска лингвистичка проучавања, док су синхронијска истраживања места топонима̂ у лексичком систему и концептуализације географских објеката неоправдано запостављена. Томе је несумњиво допринела дуготрајна научна дискусија о семантичком статусу властитих имена, која до данас није изнедри-

\footnotetext{
* Рад је написан у оквиру колективног научноистраживачког пројекта Ономастика у језичкој слици света Срба и других словенских народа, који је реализован у оквиру предмета Увод у лингвистику под руководством проф. др Људмиле Поповић.
} 
ла једногласан одговор на проблематично питање: имају ли имена значење? Од свих становишта, нама се најприкладнијим учинио став групе словенских лингвиста (Л. Шчерба, Ј. Курилович, Ф. Травничек и др.) који констатују да „имена имају значење и у језику и у говору, али различитог типа у односу на апелативе“ (према: Ахметзянова 2010: 55). Многи истраживачи истичу да именима недостаје десигнативна компонента лексичког значења. Ипак, ми сматрамо да топоними поседују своје десигнате, али у нешто друкчијем облику, што је подстакнуто чињеницом да се они неизоставно односе на јединствен и конкретан ентитет, а апелативи на читаву класу истородних објеката (Лома 2013: 11). Тако, на пример, појам Београда чини скуп базичних, али дистинктивних знања о датом конкретном објекту: главни град Србије, која деле сви или скоро сви говорници српског језика (исп. Алефиренко 2005: 204). Овој тврдњи додали бисмо још неке аргументе који сведоче у прилог томе да су топоними саставни део лексичког система ${ }^{1}$, те да су повезани са општом лексиком: 1) регуларно дејство механизма лексичке метонимије (нпр. Цео Београд жури на посао); 2) регуларни кохипонимски низови обједињени заједничком појмовном припадношћу, која је лексикализована у виду хиперонима из општег лексичког фонда (градови [Београд, Нови Сад, Ваљево]); ${ }^{2} 3$ ) деривациони потенцијал топонима̂ (нпр. Београђанин, новосадски); 4) процеси апелативизације топонима̂ (нпр. кашмир [према истоименој области]; в. Подольская 1988: 54); 5) концептуализација географских објеката означених топонимима. Сматрамо да се ниједна од ових појава не може објаснити без подлоге лексичког значења. Због свега наведеног склони смо мишљењу да су топоними семантичне речи, те ћемо их у овом раду тако и третирати. ${ }^{3}$

У раду ћемо се бавити називима делова градова - градских четврти и насеља, као и именима појединих сеоских насеља. ${ }^{4}$ Окосницу нашег истраживања чини

${ }^{1}$ Ово наглашавамо због уобичајене праксе да се имена (а међу њима и топоними) посматрају искључиво као ознаке које своју вредност добијају тек кроз употребу, док се пориче њихово место у језичком систему (в. нпр. Симић 2010: 149-154).

2 Управо у оваквим хиперонимима Алефиренко (2005: 203-204) види денотат топонима, док се референт односи на његове индивидуалне особености. Десигнат, као појам о месту, обухвата и његове опште, и индивидуалне карактеристике.

${ }^{3}$ Можда би првобитна расправа о семантичности властитих имена требало да задобије нешто ужа усмерења. Нисмо сигурни да се, на пример, семантичност антропонима̂ и топонима̂ може довести у исту раван. Топонимска структура је у оквиру једне језичке заједнице начелно непоновљива, те самим тим упућује на јединствен објекат у ванјезичкој стварности. У конкретном случају, сви говорници српског језика ће топоним Београд засигурно повезивати с једним истим ентитетом, што у крајњој линији резултира издвајањем сталних и општеприхваћених семантичких компоненти и формирањем чврсте везе између специфичног израза и садржаја. Ако и постоји могућност формалних преклапања међу топонимима, она се успешно отклања увођењем детерминатора (уп. Петровац на Млави и Петроваи на Мору, Новгород и Нижний Новгород). То, међутим, углавном не важи за антропониме.

${ }^{4}$ Називе делова градова (градских четврти и насеља) подвешћемо под термин урбаноним, а имена села̂ под термин комоним (в. Шћепановић 1997: 67). Треба истаћи да је терминолошко разграничење врста топонима̂ различито спроведено код многих других истраживача (уп. нпр. Подольская 1988). 
120 асоцијативних анкета ${ }^{5}$, које је попунило 120 испитаника различитог пола, узраста $(\approx 10-60$ година) и образовања. Експеримент је спроведен у априлу 2018. године у Београду. Свака анкета садржи укупно 100 стимулуса. Корпус се састоји од разноврсних, превасходно мање познатих назива. Одабрани топоними означавају места у различитим крајевима Србије, од чега 12 представља познатије географске објекте (углавном београдске четврти и насеља), а 88 села и градске четврти из других делова наше земље (испитаницима су ови географски објекти били већински непознати). ${ }^{6}$ Од испитаникаิ је тражено да у року од 15 минута попуне анкету и да на сваки стимулус одговоре првом речју или синтагмом која им падне на памет. Након паузе, од испитаника̂ је захтевано да покушају да објасне постанак 10 топонима за које смо претпоставили уједначеност мисаоног процеса код већине испитаника. Овај, помоћни део анкете најпре нам је послужио као начин да допремо до читавих наивних представа које се крију иза изолованих лексемних (и, знатно ређе, синтагматских) реакција из првог дела анкете (в. табелу у 2.2).

Главни циљ рада јесте да се на материјалу српског језика укаже на мноштво језичких и ванјезичких фактора који могу утицати на концептуализацију географских објеката. Приступ је превасходно когнитивистички. С тим у вези, важно је истаћи да се термини концептуализащија и концепт у овом раду употребљавају у когнитивистичком смислу. Когнитивни концепти су „комплексне дискретне јединице свести помоћу којих се остварује процес људског мишљења“ (према: Янмурзина 2014: 132). Ако пођемо од констатације да иза сваке лексеме у језику начелно стоји некакав појмовни садржај (или више њих уколико је лексема полисемична), онда је јасно зашто „за когнитивисту свакој речи одговара њен концепт“ (исп. Слышкин 2004: 23). С друге стране, само неки од тих когнитивних концепата јесу културолошки маркирани у једној заједници, и тада можемо говорити о лингвокултуролошким концептима (в. Янмурзина 2014: 132-133). Овде бисмо пре могли говорити о когнитивним концептима будући да су посреди првенствено мање познати топоними, те се знања говорника̂ претежно своде на приближну локализацију означених места, њихове знаменитости, доминантна обележја и сл., док дубља културолошка, „фонска знања“ колектива (о терминима фон, фонске семе и фонска знања в. Драгићевић 2007: 69 и Драгићевић $2011)$ углавном изостају. Многи од анализираних когнитивних концепата сиромашни су и своде се искључиво на полазну представу о некаквом географском објекту (хиперонимска идентификација „насељено место“), која се може унеколико проширити различитим асоцијацијама према самом називу. У раду ће се показати да те асоцијације најчешће не представљају културолошки фиксиране и акумулиране информације, већ жив, актуелан процес „опојмљавања“ географских објеката у свести сваког појединца. Понекад су реакције испитаника̂ на одређени топоним врло уједначене (што и даље, показаће се, у највећем броју

\footnotetext{
${ }^{5}$ Овом приликом захваљујемо се свим студентима-истраживачима (30) за велику помоћ у спровођењу анкете.

${ }^{6}$ Постојећи радови о концептуализацији географских објеката углавном се тичу општепознатих места (нпр. Москве, Русије, Америке и сл.). Ипак, сматрамо да се укључивањем непознатих стимулуса могу извести потпунији закључци о многобројним факторима који могу утицати на наш доживљај одређеног места.
} 
случајева није културално, већ когнитивно условљен факат), али су реакције неретко и врло разноврсне, чак и идиосинкратичке. Ипак, и овакве реакције су релевантне за истраживање из когнитивистичке визуре. Пишући о појму језичке слике света у когнитивистици и лингвокултурологији, Љ. Поповић (2008: 51) констатује да „когнитивнолингвистички аспект проучавања обухвата и индивидуалну когнитивну делатност говорног лица, процену удела индивидуалног искуства у колективној категоризацији и структурирању стварности“ (исп. и Слышкин 2004: 22). Дакле, не само да „свакој речи одговара њен [когнитивни] концепт" већ је и сваки тај концепт код сваког говорника прожет и индивидуалним искуствима, знањима и асоцијацијама (в. Поповић 2008: 58). ${ }^{7}$ Зато ћемо се у раду посветити и фреквентним, али и мање бројним реакцијама (нарочито у 2.1. и 2.5). Грађу нећемо детаљније анализирати из лингвокултуролошке перспективе, али ће културолошке податке читалац моћи са̂м уочити кроз реакције испитаника̂ (нарочито у 2.5).

Наравно, јасно је да се због обиља грађе, а ограниченог обима рада, не могу представити све добијене реакције. Стога ћемо настојати да сваку појаву илуструјемо задовољавајућим бројем асоцијација (с фокусом на фреквентнијим реакцијама), имајући у виду основну полазну замисао - да покажемо који су све моменти, језички и ванјезички, значајни за концептуализацију географских објеката.

Установљено је да се вербалне асоцијације могу користити и за проучавање лексичког значења (в. нпр. 3. поглавље у Драгићевић 2010). Тако ћемо и ми, на самом крају рада, прикупљени материјал размотрити из угла топонимске семантике. Покушаћемо да утврдимо да ли би неке од добијених асоцијација могле представљати семантичке компоненте топонима̂.

\section{2. Типологија реакција}

Добијене асоцијације можемо поделити на шест главних типова ${ }^{8}$ на основу природе њиховог односа према одговарајућем стимулусу:

1) нулте асоцијације, које се јављају када ниједан од доленаведених принципа обраде стимулуса није активиран или, по изузетку, када се њима свесно потискује првобитна реакција;

2) фонетске асоцијације, које се најчешће јављају као реакције на тзв. тамне речи, чија је морфемска структура за говорника крајње непрозирна; реакције овог типа налазе се у нетворбеној звуковној вези са стимулусом (нпр. Читлукчивилук, Преки шор - пешкир);

3) творбене асоцијације, које се јављају када су испитаници способни да издвоје коренску морфему стимулуса (његову апелативну основу) и помоћу ње продукују нову лексему са истим елементом (нпр. Плавинац - плав, Стражастражар); морфемска анализа не мора бити етимолошки поуздана, али стиму-

7 С друге стране, појмови као што су лингвокултуролошки концепт и (културална) конотација очишћени су од сваког индивидуалног наноса.

8 За потребе овог рада користићемо сопствену терминологију. 
лус и реакција морају стајати у неком синхроно објашњивом творбеном односу: они најчешће чине творбене парове, састављене од изведене и мотивне речи (Шупљак-шупаљ), али понекад, будући на истом нивоу изведености, образују и творбене парадигме (Шупљак-иупљина);

4) логичко-семантичке (ЛС) асоцијације, код којих се раскида свака формална веза са стимулусом, али се остварује семантичка или логичка веза са његовом апелативном основом; у оквиру њих разликујемо првостепене асоцијације, непосредно мотивисане стимулусом који у истом облику постоји и као лексема општег лексичког фонда (нпр. Јасика - дрво, Читлук-имање, Депресија - туга), и другостепене асоцијације, код којих опажамо посредовање фонетског или творбеног принципа - испрва се издваја гласовни сегмент или коренска морфема, помоћу њих се формира нова лексема, која се потом доводи у семантичку или логичку везу са другом лексемом (нпр. Барич > [бар-] > [бара] > блато);

5) трансонимске асоцијације, код којих се предложена имена тумаче унутар другог, неодговарајућег онимског домена (нпр. новосадско насеље Шангај - Кина, Кинези, нишко насеље Беверли хилс - Холивуд, гламур);

6) ванјезичке асоцијације, код којих су интегралне језичке особине стимулуса ирелевантне; место означено стимулусом везује се за одређени ванјезички контекст, који је обликован личним искуством или знањем појединца, али је неретко и стереотипизиран (нпр. Земун - криминал, Гардош - кула).

Објашњење овако широког спектра асоцијативних типова лежи у чињеници да су сакупљени називи углавном били непознати нашим испитаницима. У одсуству било какве екстралингвистичке информације о местима означеним стимулусом, испитаници су посегли за другим принципима њихове обраде. Фактор познатости по правилу покреће перцепцију ка вишим нивоима обраде стимулуса. Ако је испитаник посетио одређено место или за њега барем чуо, реакције ће углавном бити изразито емпиријски обојене. То је тенденција, али не и закон, па бележимо и незанемарљив број случајева деловања фонетског или творбеног принципа када за тим није било потребе. Овакви случајеви захтевају посебну пажњу, те ћемо их посебно размотрити у наставку рада.

2.1. Фонетске асоцијације (и њима подстакнуте другостепене ЛС асоцијације)

Фонетске асоцијације сачињавају велики део прикупљених реакција. У 18 случајева $(15 \%)$ оне су иступиле као асоцијативне доминанте у оквиру асоцијативних поља одговарајућих топонима. Ипак, треба напоменути да доминација једне фонетске реакције никада није толико изражена - оне ни у једном случају не прелазе $50 \%$ од укупног броја реакција на задати стимулус. Због несистемске природе звуковних асоцијација, дешава се да многи говорници успостављају разноврсне фонетске везе са другим лексемама. Примера ради, урбаноним Избице дао је читав спектар различитих звуковних асоцијација: избити, Ибица, убице, избеглице, шибище итд. Дате реакције су семантички неповезане. Оваква асоцијативна дисперзија карактеристична је за називе којима недостаје лексема довољно блиског гласовног склопа у систему српског језика, према којој би се мисаони процес моментално усмерио. 
Међутим, у корпусу постоје два стимулуса чија бисмо асоцијативна поља могли тумачити као својеврсне примере једносмерне доминације фонетског принципа. Тако се као најчешћа реакција на назив Мајур јавља лексема мајор $(33,33 \%)$, али и друге реакције остварују семантичку или логичку везу са поменутом асоцијативном доминантом мајор (17,5\%), што у крајњем збиру износи $50,83 \%$ укупног броја реакција. Овде се треба присетити другостепених логичко-семантичких асоцијација (в. предложену типологију реакција) које настају посредовањем фонетског принципа. Тако се унутар датог асоцијативног поља формира читава лексичко-семантичка група окупљена око фонетске доминанте мајор: титула, генерал, чин, војска, пуковник и сл. Ова појава је још израженија код урбанонима Овча, где се за доминанту овцза / овце $(45,83 \%)$ логички или семантички везује низ других реакција (15,83\%): тор, стадо, стока, јагње, гајење, поље, животињ а итд., што у крајњем збиру износи 61,66\% укупног броја реакција. Оба наведена примера повезује изразита фонетска блискост стимулуса и доминантне реакције, који заједно чине минималне парове - разликују се по свега једној фонеми. Управо се овом чињеницом може објаснити уређеност и семантичка умреженост већине реакција унутар асоцијативних поља ових двају топонима. Стога се с правом може изнети хипотеза да се око топонима̂ овог типа потенцијално могу развити живописне наивне представе код великог броја говорника, што је омогућено чврстом асоцијативном везом између топонима и лексеме из општег лексичког фонда која му је формално изразито блиска. Концептуалне токове смо најбоље испратили прегледом одговора у другом делу анкете, у којем су испитаници покушали самостално да објасне зашто ова два места имају баш такве називе. Њихова тумачења практично представљају контекстуализацију доминантних лексема-реакција. Према нашим испитаницима, Овча се, између осталог, зове тако ,јер су се тамо чувале овце“, ,,јер је свака кућа имала овцу“, ,јер тамо има много оваца“ и сл. Иако је подстицај тек звуковне природе, евидентно је да је људском уму и то сасвим довољно да створи прву, површну представу о одређеном месту.

Постоје чак и одређене индиције да је гласовна структура сваког топонима, независно од уређености и повезаности добијених реакција, незаобилазан фактор у конституисању става појединца према одређеном месту. Оваква тенденција може се повезати с појавом коју научници називају фонетским симболизмом (в. Кликовац 1995), а која се испољава на два начина: шире, парадигматски, када се односи на тежњу да се ,асоцијације успостављају међу фонетски сличним речима, без обзира на њихово порекло“ (Кликовац 1995: 178; уп. Овча и Мајур), и уже, када се односи на артикулационо-акустичке карактеристике гласова и утисак који оне производе на слушаоца (случајеви еуфоничности и какофоничности). Испитаницима из Београда навели смо имена неколико непознатих места и питали их која би од њих посетили само на основу назива. Они су, на пример, врло негативно реаговали на урбаноним Поскурище. Прегледом добијених реакција на овај стимулус установили смо да се оне углавном односе на некакве непријатне или непожељне појмове: поскок, оскудица, сахрана, сурутка, опскурно, скрама, тврдица, шкртицุа итд. Један испитаник рекао је да не би ишао у Роткварију јер „звучи одбојно и рогобатно“. Овде се као могуће објашњење намеће неколико фактора, као што је могуће успостављање везе са 
фонетским сегментом квар, какофоничност сегмента ткв, пејоративност суфикса -арија (уп. ништарија).

Евидентно је да се фонетски симболизам заиста тешко може подвргнути објективним научним испитивањима (Кликовац 1995: 175) и да су асоцијације тог типа често индивидуалне природе. Ипак, то не значи да се овим питањима не треба детаљније бавити у будућности, с обзиром на то да се „формалне и значењске везе понекад узајамно преплићу“ (Драгићевић 2007: 308). На примеру урбанонима̂ и комонима̂ показали смо да гласовна структура лексема и те како може утицати на начин на који перципирамо и организујемо стварност.

\section{2. Творбене асоцијације (и њима подстакнуте другостепене ЛС асоцијације)}

Неки истраживачи тврде да се о семантици топонима може говорити само ако је он повезан са апелативом који се налази у његовој основи (Толстој 1970: 200-201). Ипак, у литератури се често наводи да је семантичка мотивисаност топонима̂ неприступачна просечном савременом говорнику (в. Köhnlein 2015: 184). Ипак, резултати нашег истраживања оповргавају овакве научне генерализације. Словенска (а самим тим и српска) топонимија чува висок степен семантичке транспарентности, што се може објаснити њеним релативно каснијим постањем (Цветкова 2009: 139). У нашем корпусу забележено је чак 40 случајева (33,33\%) доминације творбених асоцијација, што је приметно више у односу на све друге типове. Испитаници су успешно препознавали творбене базе и форманте - њихове реакције неретко представљају управо мотивну реч стимулуса, а понекад и сасвим нову лексему са истим творбеним елементом. Илустроваћемо то на примеру двају топонима из нашег корпуса. Најфреквентније реакције на стимулус Роткварија јесу ротквица / ротквице $(37,5 \%)$ и ротква / роткве $(28,33 \%)$, уз незанемарљив број реакција које су логички или семантички повезане са творбеним доминантама $(12,5 \%)$, као што су ирвена, поврће, башта, биљка и сл. То значи да је укупно 78,33\% асоцијација добијено, посредно или непосредно, творбеним принципом. На топоним Татинаи испитаници су најчешће реаговали творбеном асоцијацијом тата $(40 \%)$, али и великим бројем других реакција $(43,33 \%)$ које су у творбеној вези са стимулусом (нпр. татко, татин) или у каквој логичкој или семантичкој вези са творбеном доминантом тата (отаи, мама, глава породице и сл.). Дакле, у датом примеру творбени принцип је, посредно или непосредно, утицао на укупно $83,33 \%$ реакција.

Како већина предложених назива није етимолошки обрађена, ми нисмо у свим случајевима могли са сигурношћу утврдити преклапају ли се савремена и историјска перспектива. Ипак, сматрамо да овом проблему и не треба приступати из угла дијахронијске анализе. За нас је далеко важнија неоспорна чињеница да је веза између топонима и њихових апелативних основа жив и емпиријски проверљив језички факат. Водећи се простим осећајем да апелативна основа сваког имена одражава суштинске карактеристике означеног места, испитаници су на овај начин осмишљавали себи дотад непознате ентитете. То се најбоље може пратити на плану метајезичких објашњења у другом делу анкете. Нека од њих навешћемо у следећој табели. 


\begin{tabular}{|l|l|l|}
\hline \multicolumn{1}{|c|}{ Стимулус } & Доминантна асоцијација & Доминантан метајезички опис \\
\hline Угљешница & угаљ & Тамо се производи угаљ. \\
\hline Татинац & тата & Тамо је много очева. \\
\hline Вучак & вук & Тамо има много вукова \\
\hline Крчагово & крчаг & Тамо се пило из крчага. \\
\hline Лебина & хлеб & Тамо се производи хлеб. \\
\hline Дуваниште & дуван & Тамо се производи дуван. \\
\hline Рибница & риба & Тамо има много риба. \\
\hline Сирча & сир & Тамо се производи сир. \\
\hline
\end{tabular}

Табела бр. 1: Метајезички опис стимулуса̂ са доминантним творбеним асоцијацијама

Примећујемо да су испитаници у својим тумачењима неретко користили облик садашњег времена. Ово указује да се веза имена са стварношћу не смешта искључиво у један историјски тренутак номинације, већ се може и актуелизовати. Потврде проналазимо и у изјавама појединих испитаника. Један од њих сматра да „у Радинцу вероватно живе поштени и вредни људи“, док „Плавинац звучи скроз некако влажно и мокро и никакво“. С друге стране, „Суводање делује суво и спарно“. Као што видимо, само на основу имена̂ изводимо различите закључке - од карактера мештана до климатских услова. Такви закључци не морају корелисати са стварношћу, али је у свести замењују или модификују.

Установили смо да фонетски принцип често рачва асоцијативно поље на мноштво различитих кракова. Изузетке од дате појаве објаснили смо на примерима топонима Овча и Мајур. Када је реч о творбеном принципу, овде се показало да, када је то могуће, он делује прилично регуларно. Творбена база стимулуса често активира асоцијације које су са њом у деривационој и(ли) семантичкој вези. Намеће се, дакле, закључак да је апелативна основа топонима важан извор концептуализације одређеног географског објекта.

\section{3. Примарне логичко-семантичке реакције}

У овом поглављу укратко ћемо се осврнути на примарне логичко-семантичке асоцијације, с обзиром на то да смо секундарне већ описали као пропратни фактор чврсте звуковне или творбене везе (в. примере у 2.1. и 2.2).

Код примарних логичко-семантичких асоцијација назив није оптерећен топонимским формантима, већ у идентичном облику постоји и као лексема општег лексичког фонда. Како су такви случајеви релативно ретки, ни не чуди што је, у поређењу с творбеним, забележен мањи број доминантних примарних логичко-семантичких реакција (19, одн. у 15,83\% случајева). Пошто овакве асоцијације нису у творбеној вези са стимулусом, њихов семантички опсег је нешто шири. Међутим, оне су и даље међусобно значењски и логички умрежене. Тако су испитаници на стимулус Стража најчешће реаговали именицом војска $(38,33 \%)$, али и другим именицама из истог домена стварности $(51,67 \%)$ : војник, касарна, затвор, полиција, гарда, чување, жандарм, тврђава и сл. Дакле, 
у овом асоцијативном пољу укупно је 90\% примарних логичко-семантичких асоцијација. Једнаку усмереност реакција могу пореметити неколики фактори: 1) полисемичност апелативне основе; на пример, стимулус Депресија поделио је своје асоцијативно поље на два крака - један, већи, окупљен око значења „психички поремећај“, и други, мањи, окупљен око значења „увала, низија“; 2) вишечланост стимулуса; на пример, на назив Ледена стена једни су реаговали фокусирајући се на целу синтагму, други на придев ледена, а трећи на именицу стена; 3) архаизација или историзација апелативне основе; на пример, више од пола испитаника није повезало топоним Читлук са спахијским имањем.

Ипак, када се остваре потребни услови, логичко-семантички принцип, као и творбени, снажно усмерава концептуалне токове. ${ }^{9}$ И овде су испитаници склони да преко семантике апелативне основе осмишљавају карактеристике места означеног стимулусом.

\section{4. Трансонимске асоцијације}

Приметили смо да су испитаници поједине стимулусе (њих 10, одн. 8,33\%) тумачили у оквиру неодговарајуће онимске категорије, што може бити подстакнуто различитим факторима. ${ }^{10}$ Прво, место може преузети име неког другог, познатог места изван Србије. У том случају запажамо концептуалну пројекцију из правца општепознатог места. Реакције су често усаглашене и стереотипизиране, у складу са владајућом медијском парадигмом. Тако се назив Беверли $x и л с$ неизоставно повезује са идеализованим холивудским животом: богаташи, богатство, милионери, раскош и сл., док на стимулус Палестина испитаници реагују сасвим супротно: pam, немири, сукоб, беда итд. Дешава се и да место преузме име знаменитости која се налази у његовој близини, као што је то случај са називом Жича, чија је доминантна реакција (65\%) именица манастир. Припадност онимској класи неретко одређујемо и према језичким карактеристикама стимулуса. Како су помоћу форманта -оњ $а$ углавном обликовани зооними, испитаници су назив Шароње у $48,33 \%$ случајева повезивали са стоком (најпре са биковима и воловима). Тако је и доминантна реакција на стимулус Маршићи-презиме (24,7\%). Понекад је важан и морфолошки облик стимулуса. Иако бисмо можда очекивали да име Јевремова Николе испитаници доживе као антропоним, најфреквентнија реакција улица (30\%) доказује да лична имена у генитиву интуитивно повезујемо са ходонимима. Занимљиво је што назив Гари испитанике преусмерава на један фиктивни зооним - на име пужа из цртаног

\footnotetext{
${ }^{9}$ Евидентно је да творбене и логичко-семантичке реакције нису међусобно супротстављене, већ их треба посматрати као својеврстан континуум. Творбене реакције, поред семантичке или логичке, задржавају и формалну везу са стимулусом, те у том смислу одражавају нешто „пасивнији“ мисаони процес, који се још увек ослања на топонимски израз. Логичкосемантичке асоцијације, примарне и секундарне, формално се удаљавају од апелативне основе стимулуса и са њом се повезују искључиво на семантичкој или логичкој равни, и у том смислу илуструју аутономнији и ,активнији“ мисаони процес (исп. ово са појмовима правих и неправих речи у Белић 1998 [1958]: 48-50).

${ }^{10}$ Треба истаћи да су испитаници били унапред обавештени да анкету чине само српски урбаноними и комоними.
} 
филма Сунђер Боб (реакције пуж и Сунђер Боб чине 30\% датог асоцијативног поља), што сведочи о снажном утицају популарне културе.

\section{5. Ванјезичке асоцијације}

На почетку рада споменули смо да испитаници никада пре анкете нису чули за већину стимулуса из нашег корпуса. То се одразило и на малу бројност ванјезичких асоцијација. Ипак, у анкету смо уврстили 12 стимулуса за које смо претпоставили да ће бити познати нашим испитаницима. На наше изненађење, на челу свега 5 асоцијативних поља $(4,17 \%)$ стајала је ванјезичка доминанта. Испоставља се да ванјезичке асоцијације доминирају само под посебним условима. То се дешава када се назив чврсто повезује са свега једном карактеристичном реалијом, знаменитошћу, личношћу и сл. Примере проналазимо у називима Сурчин и Палић, чије реакције аеродром $(47,5 \%)$ и језеро $(65,83 \%)$ доминирају својим асоцијативним пољима, уз неколицину других ванјезичких реакција (нпр. резерват, Суботица; далеко, 601) и реакција које су логички или семантички умрежене са доминантама (нпр. авион, пилот). Представићемо и друге примере, код којих је доминација ванјезичких асоцијација мање изражена. У Бранковини је можда био незнатан број људи, али је најчешћа реакција на овај стимулус Десанка Максимовић (19,17\%). То нам сведочи да емпиријски фактор није пресудан у развоју ванјезичких асоцијација, већ се у њиховој основи могу налазити и „фонска знања“, културолошке информације енциклопедијског типа. Баш напротив, установили смо да богато лично искуство понекад може знатно дестабилизовати асоцијативни процес. Иако је најфреквентнија реакција на урбаноним Земун лексема кеј $(17,5 \%)$, њена доминација није изразита због велике разуђености ванјезичких асоцијација: поље, клан, рат, криминал, архитектура, мајка, Галеника, Дунав итд. Реакције на Дорћол биле су нарочито индивидуализоване и разноврсне, али се оквирно могу издвојити три основна тематска круга: 1) окружење, знаменитости, инфраструктура, места значајна за испитанике и сл. - 28,33\% (Калемегдан, Зоолошки врт, слепе улице, фонтана, пијаца, кафане, гимназија, лепе зграде); 2) статусно-материјална одређења 10\% (богатство, богаташи, елита, имућност, лова, буржуји, аристократија); 3) дефиниције и локализација - 22,5\% (део Београда, стари део града, иченmap). Како наши испитаници несумњиво посећују ова два места чешће него, на пример, Сурчин, њихова асоцијативна поља су знатно богатија, али самим тим и неуједначенија. Не издваја се једна, већ читав спектар карактеристика. Такође, примећујемо и како се формални принципи понекад неочекивано уплићу у асоцијативна поља познатих стимулуса и тако сузбијају њихов ванјезички асоцијативни потенцијал. Иако су на назив Дедиње испитаници у $37,5 \%$ случајева реаговали статусним одређењима (богаташи, богатство, престиж, елита, виле, паре итд.), овде се запажа и изражена интерференција формалних и секундарних логичко-семантичких принципа, па је најфреквентнија асоцијација $(23,33 \%)$ управо творбене природе: деда. ${ }^{11}$ Асоцијативна поља стимулуса Миријево, Палилула, Карабурма, Добановци и Овча укратко ћемо пред-

${ }^{11}$ Ово бисмо делимично могли приписати општој усмерености мисаоног процеса током читаве анкете, али и већ поменутој регуларности примене творбеног принципа. 
ставити у следећој табели.

\begin{tabular}{|l|l|l|}
\hline \multicolumn{1}{|c|}{ Стимулус } & \multicolumn{1}{|c|}{ Најфреквентнија асоцијација } \\
и њен тип & \multicolumn{1}{|c|}{$\begin{array}{c}\text { Проценат } \\
\text { ванјезичких } \\
\text { асоцијација }\end{array}$} \\
\hline Миријево & мир $(23,33 \%)$, творбена асоцијација & $39,17 \%$ \\
\hline Палилула & лула $(28,33 \%)$, творбена асоцијација & $25,83 \%$ \\
\hline Карабурма & бурма $(12,5 \%)$, творбена асоцијација & $35 \%$ \\
\hline Добановци & бан $(10 \%)$, творбена асоцијација & $26,66 \%$ \\
\hline Овча & овцุа / овцее $(45,83 \%)$, фонетска асоцијација & $23,33 \%$ \\
\hline
\end{tabular}

Табела бр. 2: АП стимулуса Миријево, Палилула, Карабурма, Добановии и Овча

Премда су и ови топоними били познати испитаницима, у њиховим асоцијативним пољима не доминирају ванјезичке реакције. Ово је вероватно узроковано и чињеницом да су знања испитаника̂ о датим местима била врло базична (нпр. приближно одређење њиховог географског положаја). Иако је, према нашем мишљењу, сема локализације у самој сржи лексичког значења топонима̂, она, очигледно, за асоцијативне токове није нарочито важна. Евидентно је да таква информација не привлачи пажњу већине испитаника јер није довољно специфична, те овде по бројности предњаче фонетске и творбене реакције.

Установили смо да се једносмерна и изражена асоцијативна доминација на ванјезичком нивоу остварује само када постоји једна реалија као општепозната differentia specifica означеног места (исп. Палић и Сурчин). Када је географски објекат искуствено ближи говорницима, али се не издваја једном својом упечатљивом карактеристиком, ванјезички принцип је доминантан, али је тада асоцијативно поље разуђено и испарцелисано разноврсним асоцијацијама (често и идиосинкратичким) приближно једнаке фреквенције (исп. Земун и Дорћол). Када је одређено место и емпиријски удаљеније говорницима, и неутрално по питању општепознатих маркантних обележја, онда примећујемо значајно уплитање формалних (фонетских и творбених) принципа (исп. Миријево, Палилулу, Карабурму, Добановцее и Овчу).

\section{6. Нулте асоцијације}

Постоје различити фактори који утичу на појаву нултих реакција. То је, пре свега, формално-семантичка непрозирност топонима, због које се не активира ниједан од описаних принципа обраде стимулуса. Ипак, случајеве омисије срећемо и код познатих стимулуса, када говорник, међутим, доступну информацију не доживљава као релевантну (нпр. нулте асоцијације на урбаноним Дорћол). Овакав тип омисије назвали бисмо спонтаном.

Међутим, забележили смо и мањи број нултих реакција које не можемо 
објаснити горенаведеним узроцима. Наиме, у анкети се нашло и неколико назива за које смо претпоставили да би код испитаника̂ могли изазвати непристојне или вулгарне асоцијације. Они у основи поседују изражен асоцијативни потенцијал, који је „на папиру“ значајно умањен зато што испитаници свесно блокирају одређене реакције јер их сматрају неподеснима за дату прилику. ${ }^{12}$ Називи Пишура и Сисевац тако се у коначном збиру налазе при врху када говоримо о заступљености нултих асоцијација: у првом случају одговор је изостао у $17,5 \%$, а у другом у 10,83\% случајева. Овај тип омисије можемо назвати намерном или прохибиторном, а он је нарочито значајан јер нам открива који су појмови у свести говорника̂ табуизирани. ${ }^{13}$

Евидентно је да и нулте реакције посредно могу одражавати поједине фрагменте слике света једног народа. Ипак, регуларност, условљеност и функције ове појаве ваљало би детаљније размотрити на већем и разноврснијем корпусу.

\section{3. Закључна разматрања}

У овом поглављу укратко ћемо изнети главне закључке рада. Такође, вратићемо се проблему топонимске семантике с почетка рада. Покушаћемо да одредимо у ком односу стоје добијене реакције према лексичком значењу, а у којем према језичкој слици света.

Установили смо да фонетске асоцијације углавном немају системски карактер, због чега су врло разноврсне. Тако једног испитаника урбаноним Салајка својим гласовним склопом подсећа на салаш, другог на сало, трећег на салу итд. Како се појмови језичке слике света (барем у свом типичном лингвокултуролошком, националном одређењу; в. Попова, Стернин 2007: 21) и лексичког значења приписују целој говорној заједници, овакве реакције не можемо довести у везу ни са једном од датих категорија. Исто важи и за фонетски симболизам у ужем смислу - еуфоничност и какофоничност, будући да су и ове појаве углавном индивидуалне природе (исп. Драгићевић 2007: 60). Ипак, показали смо да звуковни подстицаји и те како могу обликовати концептуалне токове појединца. Зато би се асоцијације овог типа најпре могле сместити у домен индивидуалне језичке слике света.

Добијене творбене и логичко-семантичке реакције одражавају општу тенденцију да карактеристике неког места осмишљавамо преко значења апелативне основе његовог назива. Када се за њих остваре потребни услови, реакције овог типа јављају се врло регуларно, због чега можемо претпоставити њихову већу распрострањеност. Међутим, како појам лексичког значења подразумева везу са стварношћу (Драгићевић 2007: 54), а апелативна семантика најчешће не одражава актуелне карактеристике именованог објекта, овакве асоцијације (и концепте образоване око њих) можемо третирати као део наивне слике света, која због сличних језичких, ванјезичких и когнитивних фактора може бити заједничка већем броју припадника одређеног језичког колектива. Ипак, постоје и ретки случајеви када се апелативна основа топонима и данас може повезати

\footnotetext{
${ }^{12}$ Тенденцију запажамо упркос томе што је анкета анонимна.

${ }^{13}$ Такође, овакви случајеви указују на извесне недостатке асоцијативне методе.
} 
са његовим значењем. То се углавном односи на сеоска насеља која су добила имена према одликама свог рељефа, који често одолева зубу времена. Тако, на пример, комоним Планиница означава место које одликује брдовито и планинско земљиште (Павловић 2012). Можемо констатовати да у овом случају поменута сема изгледа улази у шире значење датог топонима. Исто можемо тврдити и за практично све новонастале топониме, ако претпоставимо да су скоро сви топоними мотивисани неким апелативом. Значење апелатива има удела у топонимској семантици све док говорници препознају апелативну основу и све док се њено значење може довести у везу са стварним изгледом места.

Што се тиче трансонимских реакција, посебну пажњу треба обратити на топониме који су мотивисани називима оближњих знаменитости и сл. Ако се место зове Жича, то нам засигурно указује да се у његовој близини налази истоимени манастир. Према нашој оцени, оваква информација такође улази у сферу лексичког значења топонима.

Прохибиторне нулте реакције показале су нам да се вулгарна конотативна маркираност апелативне основе понекад може пренети и на са̂м топоним. Ипак, као што смо већ нагласили, овакве тврдње требало би поткрепити детаљнијим испитивањима.

Установили смо да ванјезичке реакције углавном одликује изразита индивидуалност и субјективност. Ипак, на примеру урбанонима Дорћол показали смо да се мноштво добијених реакција може свести на неколико упечатљивих тематских кругова, који осветљавају дати географски објект са различитих становишта. Међутим, дешава се и да назив сви говорници повезују са једном истом реалијом по којој је означено место препознатљиво: Палић - језеро, Сурчин аеродром. Према нашем мишљењу, језеро и аеродром представљају важне компоненте лексичког значења топонима Палић и Сурчин.

Сматрамо да су сви ови моменти важни за разумевање природе топонима̂ као значајног слоја лексичког система српског језика и „лексикализованих елемената културе“" (Filipović 2018: 23). Како се о топонимима из синхронијске перспективе досад није много писало на нашим просторима, овај рад представља тек скромни допринос питањима која би у будућности ваљало темељније истражити, и то на већем корпусу и уз примену додатних методолошких процедура.

\section{Цитирана литература}

Алефиренко, Николай Ф. Спорные проблемы семантики. Москва: Гнозис, 2005. Ахметзянова, Лиана М. «Проблема семантики имени собственного». Вестник

Казанского государственного университета культуры и искусств 3, 2010: 50-56. Белић, Александар. О језичкој природи и језичком развитку, књ. 1 и 2. Изабрана дела. Први том. Општа лингвистика. Београд: Завод за уџбенике, 1998.

Драгићевић, Рајна. Лексикологија српског језика. Београд: Завод за уџбенике, 2007. Драгићевић, Рајна. Вербалне асоцијације кроз српски језик и културу. Београд:

Друштво за српски језик и књижевност Србије, 2010.

Драгићевић, Рајна. „Лингвокултуролошки приступ у настави српског као страног 
језика“. [У:] В. Крајишник (ур.) Српски као страни језик у теорији и пракси II, тематски зборник радова. Београд: Филолошки факултет, 2011, 81-95.

Кликовац, Душка. „Ври, штркља, кљечка: о фонетском симболизму у српскохрватском језику“. Зборник Матице српске за лингвистику XXXVIII/1, 1995: 175-184.

Лома, Александар. Топонимија Бањске хрисовуље. Београд: Српска академија наука и уметности, 2013.

Павловић, Љубомир. Колубара и Подгорина: насеља, порекло становништва, обичаји, књига 15. Београд: Службени гласник, 2012.

Подољская, Наталия В. Словарь русской ономастической терминологии. Москва: Наука, 1988.

Попова, Зинаида Д., Иосиф А. Стернин. Когнитивная лингвистика. Москва: АСТ: «Восток - Запад», 2007.

Поповић, Људмила. Језичка слика стварности: когнитивни аспект контрастивне анализе. Београд: Филолошки факултет, 2008.

Симић, Радоје. Стилистика српског језика. Београд: НДСЈ и Јасен, 2010.

Слышкин, Геннадий Г. Лингвокультурные концепты и метаконцепты (диссертация на соискание ученой степени доктора филологических наук). Волгоград: 2004

Толстой, Никита И. «Еще раз о семантике имени собственного». [В:] Актуальные проблемы лексикологии. Тезисы докладов и сообщений Всесоюзной научной конференции. Минск: БГУ, 1970, 200-201.

Цветкова, Елена В. «К вопросу о семантике топонимов». Вестник Костромского государственного университета им. Н. А. Некрасова, н. 2, 2009: 139-143.

Шћепановић, Михаило. „Ономастичке категорије и српска ономастичка терминологија“. Књижевност и језик XLV/2-3, 1997: 65-70.

Янмурзина, Рамиля Р. «Когнитивная лингвистика и лингвокультурология: черты и различия». Вестник Башкирского университета, 2014: 132-135.

Filipović, Jelena. Moć reči: ogledi iz kritičke sociolingvistike, 2. izd. Beograd: Zadužbina Andrejević, 2018.

Köhnlein, Björn. The morphological structure of complex place names: the case of Dutch. The Journal of Comparative Germanic Linguistics, Volume 18, Issue 3, 2015: 183-212.

\section{Матия Нешович}

\section{НАЗВАНИЯ СЕРБСКИХ ДЕРЕВЕНЬ И ЧАСТЕЙ ГОРОДОВ В ВЕРБАЛЬНЫХ АССОЦИАЦИЯХ НОСИТЕЛЕЙ СЕРБСКОГО ЯЗЫКА}

\section{Резюме}

В данной работе на основе результатов ассоциативного эксперимента анализируется сто сербских топонимов, а именно названий частей городов и деревень в Сербии. В работе сделана попытка выдвинуть все языковые и внеязыковые факторы, значимые для концептуализации географических объектов. Таким образом создается более четкое представление о природе концептуализации географических объектов. Исследование показало, что реакции могут быть соотнесены с личным опытом, но иногда и только с лингвистическими характеристиками стимула. Несмотря на то, что в работе в первую очередь используется когнитивный подход, в 
некоторых ассоциациях можно обнаружить и определенную культурологическую информацию. Помимо этого, в статье обсуждается вопрос о семантике топонимов и рассматривается отношение некоторых типов реакций к лексическому значению топонимов.

Ключевые слова: топонимы, концептуализация, ассоциативный эксперимент, семантика топонимов, сербский язык. 